\title{
Priming Effects on Verb Production as a Function of Semantic Richness in Persons with Aphasia
}

\author{
Gyu Yeon Kim, Jee Eun Sung \\ Department of Communication Disorders, Ewha Womans University, Seoul, Korea
}

Correspondence: Jee Eun Sung, PhD Department of Communication Disorders, Ewha Womans University, 52 Ewhayeodae-gil, Seodaemun-gu, Seoul 03760, Korea

Tel: $+82-2-3277-2208$

Fax: +82-2-3277-2122

E-mail: jeesung@ewha.ac.kr

Received: January 5, 2021

Revised: January 25, 2021

Accepted: January 25, 2021

This work was supported by the Ministry of Education of the Republic of Korea and the National Research Foundation of Korea (NRF2019R1A2C1089280).

\begin{abstract}
Objectives: The goal of this study was to explore the effect of priming verbs between individuals with aphasia and normal adults through a verb priming task. Methods: A total of 26 adults, including thirteen individuals with aphasia and thirteen normal adults with consistent age, years of education, and gender participated in this experiment. This study developed a verb priming task by referring to the task used in the research by Kim \& Thompson (2004). After conducting the verb priming task, this study analyzed the priming verb computation rate and error types in each group. Results: The priming verb computation rate was significantly lower in the group of individuals with aphasia than in the normal adult group, and the priming rate of light verbs was significantly lower than that of heavy verbs. However, the correlation between group-verb type was not significant. The analysis of the error types of individuals with aphasia showed verb type conversion regardless of verb type. The ratio of major error responses was higher than correct responses in light verbs, while the ratio of correct responses was higher than major error responses in heavy verbs. Conclusion: This study implies that Korean language individuals with aphasia have more difficulties with computation in light verbs than in heavy verbs, which in a tendency also shown among normal adults and reflects the normal linguistic characteristics of the Korean language. In this study, the difficulties of light verb computation can be explained by the combination of 'predicate noun+light verb'. The combination of 'predicate noun+light verb' became more difficult as nominal and proverbial characteristics of predicate nouns were added to the proverbial characteristics of light verbs.
\end{abstract}

Keywords: Aphasia, Priming effect, Light verb, Heavy verb, Verb subtype
실어증의 주요 원인은 뇌졸중이며, 뇌 손상 환자의 발생률은 지 속적으로 상승하고 있다(Ministry of the Interior and Safety, 2009). Godefroy, Dubois, Debachy, Leclerc와 Kreisler (2002)에 따 르면 308 명의 뇌졸중 환자들을 3 년간 추적연구한 결과, $75 \%$ 의 환 자들은 다양한 언어적 증상을 포함한 실어증이 나타났다고 한다. 실어증 환자가 증가함에 따라 실어증 환자의 언어 재활은 현 시점 에서 필수적인 과제로 직면했다. 이에 실어증 환자의 면밀한 평가와 증거기반 중재를 위한 실어증 환자의 언어 손상에 대한 기초 연구 가 필요하다. 실어증 환자가 보이는 다양한 언어 문제 중 특히 두드 러지는 언어 손상은 단어 인출의 문제이다(Berndt, Haendiges, Mitchum, \& Sandson, 1997; Zingeser \& Berndt, 1990). 실어증 환 자를 대상으로 한 단어 인출에 대한 연구는 과거에는 주로 명사에
초점을 맞추었으나, 최근 연구에 따르면 실어증 환자는 동사 이름대 기에 더욱 어려움을 보인다(Berndt, Mitchum, Haendiges, \& Sandson, 1997; De Bleser \& Kauschke, 2003; Kim \& Thompson, 2000, 2004). 그 이유는 동사는 명사와 달리 사물의 움직임을 나타내어 시각화하기 어려우며(Berndt, Mitchum et al., 1997), 시제나 문장 구조에 따라 형태가 바뀐다(Lilla, 1990; White-Devine, Grossman, Robinson, Onishi, \& Biassou, 1996)는 점에서 찾을 수 있다.

실어증 환자의 동사 처리 연구에서, 실어증 환자들은 동사의 특 정 범주별로 손상 정도가 다름이 밝혀졌다(Kim \& Thompson, 2000; Kiss, 2000; Yoon \& Kim, 2002). Kim과 Thompson (2000)은 실어증 환자에게 논항을 기준으로 동사를 분류하여 이름대기를 실시하였다. 실험 결과, 실어증 환자들은 논항의 수가 많아질수록 
표현의 어려움을 보였다. Breedin과 Martin (1996)은 의미적 범주 로 동사를 분류하여 실어증 환자의 동사 이해 및 산출 과제를 실시 하였다. 그 결과 동사의 유형에 따라 결함이 다르게 나타남을 밝혀 냈다.

경동사는 'make, do, take'와 같이 중동사로 사용되던 동사의 의 미가 탈의미화되어 의미 기능이 감소하여 동사의 형태를 갖추고 있 으나 의미적으로 비어있는 동사를 의미한다. 경동사의 특징을 살펴 보면 1) 의미적으로 비어있으며, 2) 논항 구조를 갖지 않고, 3) 의미 역 또한 갖고 있지 않다고 볼 수 있다. 반면, 중동사는 일반동사의 형태로 1) 그 자체로 의미를 갖고 있으며, 2) 논항 구조와 3) 의미역 을 가진다고 볼 수 있다. 영어의 경동사는 뒤따르는 명사에 따라 선 택적으로 사용되어지는 반면, 한국어의 경동사는 하나의 경동사가 많은 서술명사와 결합하여 다양하게 사용되어진다. 이러한 한국어 의 경동사에 대한 논의가 여러 학자들에 의해 진행되었다. 한국어 의 경동사는 서술명사에 결합하여 그것의 문법 범주가 실현될 수 있도록 하는 버팀목 같은 역할을 한다(Park, 2014). 즉, 서술명사+ 경동사 복합체의 의미는 서술명사에 의해 전적으로 결정되며 경동 사는 문법적인 기능을 하고 있으며, 이는 경동사가 구문적인 핵심 일지라도 핵심 의미는 서술명사가 지니고 있다는 것이다.

경동사 및 중동사에 대한 연구를 살펴보면 다음과 같다. 실어증 환자의 경동사와 중동사에 따른 인출 능력을 지연반복-문장완성 과제를 통해 확인한 결과, 실어증 환자들은 경동사보다 중동사에 서 높은 산출 능력을 보였다(Sarah, Eleanor, \& Myrna, 1998). Kim 과 Thompson (2004)의 연구에서는 실어증 환자와 정상 성인이 담 화 산출 시 중동사 사용 빈도가 경동사 사용 빈도보다 유의하게 높 았다는 사실을 밝혔다. 또한, 실어증 환자와 정상 성인이 Probable Alzheimer's Disease (PrAD)에 비해 중동사 산출 능력이 유의하게 높았다는 사실을 밝혔다. 즉, $\mathrm{PrAD}$ 군은 정상 성인에 비해 중동사 산출 비율이 낮고, 상대적으로 경동사 산출 비율이 높았다고 할 수 있는 결과를 보였다. 반면 실어증 환자군은 정상 성인군과 정반응 률에서 유의한 차이는 있었으나 비율 양상이 유사하게 나타났다. Diane (2017)은 비유창형 실어증 환자, 유창형 실어증 환자 그리고 정상 통제 집단에게 Sarah 등(1998)의 지연반복-문장완성 과제를 의미적, 통사적으로 통제 및 보완하여 실시하였다. 실어증 환자 집 단에 비해 정상 통제 집단에서 유의하게 정반응률이 높았으나, 실 어증 환자 집단 내에서 유의한 차이가 나타나지 않았다. 또한 실어 증 환자 집단의 경동사 및 중동사산출 정확도 및 산출 빈도가 유의 한 차이가 없었다. 이러한 연구 결과는 Sharah 등(1998)의 연구와 다른 결과를 보인다. 이처럼 경동사 및 중동사의 분류에 따른 연구 는 일치되지 않은 결과를 보이고 여전히 논의되는 문제이며, 이에
대한 연구의 수 역시 미비하다. 특히 국내에서 경동사와 중동사로 분류하여 실시된 연구는 매우 부족한 실정이다.

한국어에서 동사는 문장을 이루는 중요한 성분이다. 한국어의 동사는 영어와 달리 문장의 끝에 위치하여 문장에 본 역할을 다 할 수 있도록 한다(Nam, 2001). 한국어는 동사로 끝나는 동사 핵심 언 어로(Park, 2012), 동사의 사용에 있어 영어와는 차이가 있다. 한국 어에는 특징적으로 서술명사와 경동사가 자유롭게 결합하여 사용 되어 지는 경우가 많다. Kang과 Kim (2009)의 말뭉치에서도 가장 높은 빈도의 단어는 '하다'로, 한국어에서는 경동사와 결합하는 서 술명사에 따라 종류가 다양하고 높은 빈도로 사용됨을 알 수 있다.

본 연구에서는 Kim과 Thompson (2004)의 문장완성 과제를 참 고하여 연구도구를 제작하였다. 동사 점화 과제는 목표문장을 이 끌어 낼 수 있는 그림자극과 문장자극을 선행 제시하고 목표문장 을 산출하기 위한 그림을 제시하여 목표문장을 유도시킨다. 동사 는 실어증 환자군의 차별화된 수행력을 설명하는 데 중요한 요소 로서 다양한 언어권에서 연구되고 있으나 한국어를 대상으로 한 연구는 매우 제한적이며(Sung \& Kwak, 2012), 동사를 분류하여 실 시된 연구는 부족하여 본 연구가 실어증 환자의 동사 손상을 살펴 보는 기초 자료가 될 수 있다. 따라서, 경동사와 중동사로 나누어 실 어증 환자의 점화 효과가 어떠한 차이가 있는지 살펴보고자 한다. 연구 질문은 아래와 같다.

첫째, 경동사 및 중동사 점화에 따른 점화 동사산출 비율에서 정 상 집단과 실어증 집단 간 차이가 유의한가?

둘째, 동사 점화 과제에서 실어증 환자 집단은 동사 유형에 따른 정반응-오반응 유형별 차이를 보이는가?

\section{연구방법}

\section{연구대상}

본 연구의 대상자는 실어증 환자 13 명과 정상 성인 13 명, 총 26 명 이 참여하였다. 본 연구는 연구에 참여하는 대상자에게 연구의 목 적과 실험 내용, 방법 및 절차, 소요 시간 등에 대한 안내를 사전에 진행하였고 이에 동의한다는 서명을 받았으며 생명윤리위원회의 승인을 받아 진행하였다(IRB No. 201908-0024-01). 두 집단은 모 두 (1) 한국어를 모국어로 사용하고, (2) 오른손잡이이며, (3) 서울 신경심리검사 2판(Seoul Neuropsychologic Screening Battery-II, SNSB-II; Kang \& Na, 2003)의 하위검사 글자 지우기(Letter Cancellation) 과제를 통해 무시 증후군이 없는 자로 선정하였다.

실어증 환자는 (1) 좌뇌 피질, 피질하 부위의 뇌졸중으로 인하여 언어장애가 나타난 자, (2) 파라다이스 한국판 웨스턴 실어증검사- 
개정판(Paradise Korean Version-Western Aphasia Battery-R, PKWAB-R; Kim \& Na, 2012) 결과 실어증으로 분류된 자, (3) 발병 이 전 뇌손상과 기타 신경학적 병력이 없었다고 보고된 자, (4) 검사 내 용 및 지시에 대한 이해가 가능하여야 하므로 PK-WAB-R 결과 알 아듣기 항목의 점수가 5점 이상인 자로 선정하였다.

정상 성인은 (1) 실어증 환자군의 평균 연령과 평균 교육연수, 그 리고 성별을 일치시킨 자, (2) 건강 선별기준(Christensen, Multhaup, Nordstrom, \& Voss, 1991)에 근거하여 신경과 또는 정신과적 병력 이나 두뇌 손상 병력이 보고되지 않은 자, (3) 한국형 간이정신상태 검사(Korean-Mini Mental State Examination, K-MMSE; Kang, $\mathrm{Na}, \& \mathrm{Hahn}, 1997)$ 점수가 연령 및 교육연수에 비해 $16 \%$ ile 이상으 로 정상 범위에 해당하는 자, (4) SNSB-II의 하위검사인 서울구어 학습검사(Seoul Verbal Learning Test, SVLT)에서 점수가 연령 및 교육연수에 비해 $16 \%$ ile 이상으로 정상 범위에 해당하는 자, (5) 그 외의 언어 및 인지적, 신경학적 손상, 발달적 병력이 보고되지 않은 성인들을 대상으로 하였다.

본 연구에 참여한 집단별 연령과 교육연수가 통계적으로 유의한 차이가 있는지 알아보기 위해 각각 독립표본 $t$-검정(two-independent sample $t$-test)을 실시하였다. 그 결과, 두 집단의 연령과 교육연 수에는 통계적으로 유의한 차이가 없었다(Table 1).

\section{연구과제}

동사 점화 과제(verb priming task)

동사 하위 유형을 경동사 및 중동사로 나누어 점화 효과를 확인 하기 위한 과제로 동사 점화 과제(verb priming task)를 사용하였 다. 동사 점화 과제의 동사는 다음과 같은 기준으로 선정하였다. (1) 경동사와 중동사가 의미적으로 쌍을 이루는 동사, (2) 현대 한국어 의 어휘 빈도(Seo, 1998 )에서 고빈도 및 최고빈도 동사, 혹은 현대 국어 사용 빈도 조사(National Institute of Korean Language, 2010)에서 고빈도 동사, (3) 단어의 길이는 2-4음절인 동사로 제한 하였으며, (4) 그림으로 표현이 가능한 움직임을 나타내는 동사, (5) 점화 동사와 의미적으로 관련되어 있으나 그림 상 명확하게 다른 행동으로 그려질 수 있는 동사로 선정하였다.

Table 1. Demographic information on participants

\begin{tabular}{lccc}
\hline & $\begin{array}{c}\text { Normal control } \\
\text { group (N=13) }\end{array}$ & $\begin{array}{c}\text { Participants with } \\
\text { aphasia (N=13) }\end{array}$ & $t$ \\
\hline Age (yr) & $52.15(3.95)$ & $53.38(10.09)$ & 0.41 \\
Education (yr) & $12.61(2.33)$ & $13.85(2.99)$ & 1.17 \\
Male:Female & $11: 02$ & $11: 02$ & \\
\hline
\end{tabular}

Values are presented as mean (SD).
선정된 문장 쌍의 그림 자료는 가로 $20 \mathrm{~cm} \times$ 세로 $15 \mathrm{~cm}$ 로 제작 된 흑백의 선화로 움직임을 묘사할 수 있도록 그려졌다. 그림에 방 향성 등 목표 단어를 구체화할 필요가 있는 항목에 대해서는 화살 표 및 점선을 첨가하였다.

자극 목록에 대한 타당도를 확인하기 위해, 동사 쌍에 대해 언어 학 및 언어병리학 전공 성인 20 명에게 점화 동사와 목표 동사간 의 미적 관련성을 1 점(매우 관련 없음)부터 7점(매우 관련 있음)으로 7 점 척도로 평가를 실시하고, 6.4점으로 나타났다. 또한, 그림 자료는 정상 청년 20명에게 그림 내용과 문장 내용이 얼마나 일치하는지 1 점(매우 일치하지 않음)부터 7점(매우 일치함)으로 7점 척도로 측 정하도록 하였다. 그 결과 6.8 점으로 나타났다. 동사 점화 과제의 그 림 자극 예시는 Figure 1과 같으며 전체 문장 자극은 Appendix 1에 제시하였다.

\section{연구절차}

모든 대상자에게 개별적으로 인지 및 언어 선별 검사를 실시한 후, 실험 내용과 절차에 대해 안내하였다. 이때 대상자가 실험 과정 을 숙지할 수 있도록 검사자의 개인 노트북을 통해 사전에 제작된 안내사항을 함께 제공하였다. 그리고 3 개의 연습문항을 통해 과제 를 충분히 숙지한 후 본 과제를 실시하였다. 연습문항 시행 과정에 서는 연구자가 지시내용을 다시 들려주거나 대상자의 응답에 피드 백을 제공하였다. 대상자마다 과제 내 제공되는 문항의 순서는 모 두 다르게 실시하였다.

연구자는 대상자에게 다음과 같이 과제 제시문을 제공하였다.

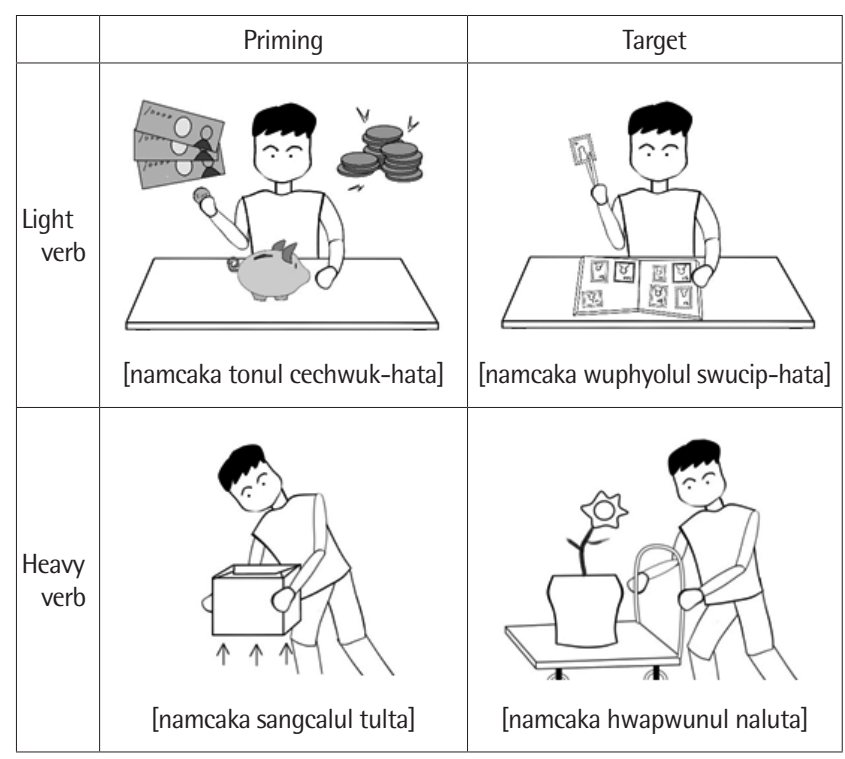

Figure 1. An example of verb priming task. 
“지금부터 그림을 보여드리겠습니다. 첫 번째 그림이 제시되면 제 가 그림을 설명하는 문장을 들려드립니다. 이후 두 번째 그림이 제 시됩니다. 그 그림을 보시고 문장으로 설명해주시면 됩니다." 대상 자가 지시를 충분히 이해하지 못하였으면 1 회 다시 들려주었다. 치 료사는 목표 문장을 유도하는 그림을 제공한 후 대상자의 반응을 기다렸다. 만약 그림이 제공된 후 15 초 동안 대상자가 반응을 보이 지 않으면, 다시 지시를 들려주었다. 본 과제가 진행되는 동안은 대 상자에게 의미적, 음소적, 시각적 단서를 제공하지 않았고, 대상자 의 반응에 대한 어떠한 피드백도 제공하지 않았다. 대상자의 모든 반응은 녹음기를 통해 녹음하였으며, 결과 기록지에 기입하였다.

\section{자료분석}

\section{점화 동사 산출률}

점화 동사의 유형에 따라 대상자가 점화 동사와 같은 동사 유형 을 산출했는지 여부를 확인하였다. 점화 동사와 같은 동사 유형을 산출한 문항은 1 점, 점화 동사 유형으로 산출하지 않은 문항은 0 점 으로 계산하였다. 실험을 실시하는 동안 무반응 및 오류 반응을 보 이거나, 모른다고 답한 경우 모두 0 점으로 처리한 후 기록지에 대상 자의 반응을 기록하였다.

각 동사 유형별로 반응을 기록하여 정반응을 보인 문항 수를 전 체 문항 수로 나눈 후 100 을 곱하여 점화 동사 산출률(\%)을 계산하 였다.

\section{오류 유형 분석}

대상자의 오류 반응에 대해서는 타 유형 서술어 전환(동사 유형 전환, 형용사 전환), 점화 동사 반복, 착어, 신조어, 코딩불가, 관련없 는 반응으로 분류하였다. 오류 반응의 예시와 설명은 Appendix 2 에 제시하였다.

\section{통계적 처리}

자료의 통계적 처리는 SPSS version 26.0 for Windows 프로그램 을 이용하여 통계적 분석을 실시하였다. 점화 자극(경동사, 중동사) 의 차이에 따른 두 집단(실어증 환자, 정상 성인) 간 차이를 알아보 기 위해 이원혼합분산분석(two-way mixed ANOVA)을 실시하였

Table 2. Descriptive statistics of priming verb accuracy rate (\%) for each group

\begin{tabular}{lcc}
\hline & Light verb & Heavy verb \\
\hline Normal group $(\mathrm{N}=13)$ & $72.23(17.54)$ & $90.31(10.04)$ \\
Aphasia group $(\mathrm{N}=13)$ & $37.06(20.10)$ & $60.13(25.38)$ \\
\hline
\end{tabular}

Values are presented as mean (SD).
다. 동사 점화 과제에서 실어증 집단 내 동사 유형에 따른 정반응-주 요 오반응 비율의 차이가 있는지 알아보기 위해 카이 제곱 검정을 실시하였다.

\section{신뢰도}

실어증 환자의 동사 점화 효과에 대한 신뢰도를 평가하기 위해 전체 대상자의 $10 \%$ 에 해당하는 자료를 무작위로 추출하여 실시하 였다. 제 1 평가자는 연구자이며 제 2 평가자는 언어병리학 석사학위 자로 2 급 언어재활사이다. 제 1 평가자가 채점 기준에 따라 분석과 채점을 실시하고 제 2 평가자는 분석 기준을 숙지한 뒤 독립적으로 채점하도록 하였다. 신뢰도는 평가자 간 일치한 문항 개수를 총 문 항 개수로 나누어 신뢰도를 산출하였다. 그 결과 점화 동사 산출률 에 대한 신뢰도는 $98.2 \%$ 였으며, 오류 유형 분석에 대한 신뢰도는 $96.7 \%$ 였다.

\section{연구결과}

\section{점화 동사 유형(경동사/중동사)에 따라 동사 점화 과제에서의 집단 간 점화 동사 산출률 분석}

정상 성인 집단과 실어증 환자 집단 간의 점화 동사 산출률에 대 한 기술통계 값은 Table 2, Figure 2와 같다.

점화 동사 유형에 따른 집단 간 점화 동사 산출률에 차이가 있는 지 알아보기 위해 이원혼합분산분석을 실시한 결과는 다음과 같다.

점화 동사 유형에 따른 집단 간 점화 동사 산출률에 대한 분산분 석 결과, 실어증 환자와 정상 성인에 대한 주효과가 통계적으로 유 의하였다 $\left(F_{(1,24)}=31.026, p<.001\right)$. 즉, 정상 성인 집단의 점화 동사 산출률 $(\mathrm{M}=81.27)$ 이 실어증 환자의 점화 동사 산출률 $(\mathrm{M}=47.58)$ 보다 유의하게 더 높은 것으로 나타났다.

점화 동사 유형에 따른 점화 동사 산출률에 대한 주효과가 통계

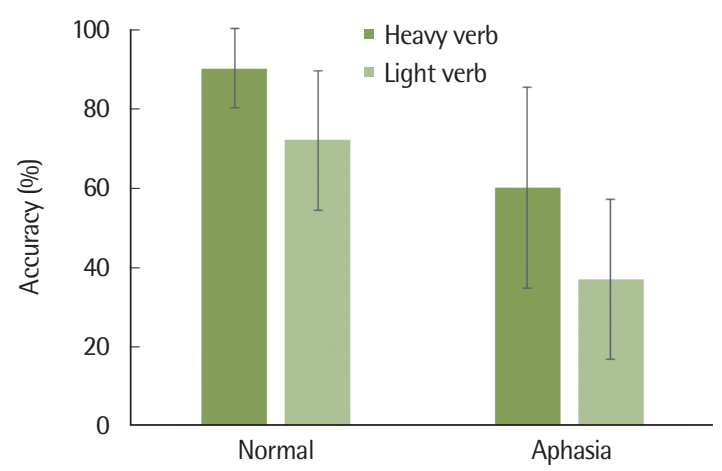

Figure 2. The accuracy rate of priming verb (\%) in each group. 
적으로 유의하였다 $\left(\mathrm{F}_{(1,24)}=18.574, p<.001\right)$. 즉, 점화 동사 유형 중 중동사 $(\mathrm{M}=73.93)$ 가 경동사 $(\mathrm{M}=54.93)$ 보다 점화 동사 산출률이 유의하게 더 높은 것으로 나타났다.

점화 동사 유형에 따른 집단 간 상호작용이 통계적으로 유의하 지 않았다 $\left(F_{(1,24)}=0.44, p>.05\right)$. 즉, 점화 동사 유형에 따른 점화 동 사 산출률의 차이가 정상 성인 집단과 실어증 환자 집단 사이에서 유의한 차이가 나타나지 않았다.

\section{실어증 환자의 동사 유형별 오류 분석}

\section{오류 유형 분석}

실어증 환자군이 보인 오류 반응을 분석하여 동사 유형별로 실 어증 환자 집단의 오류 반응을 살펴보면 다음과 같다. 중동사에서 나타난 전체 오류 57 개 중 동사 유형 전환이 37 개(64.91\%), 관련없 는 반응 10 개(17.54\%), 형용사 전환, 코딩불가, 점화 동사 반복이 각 3 개(5.26\%), 신조어 1 개(1.75\%)로 나타났다. 경동사에서 나타난 전 체 오류 90 개 중 동사 유형 전환 68개(77.27\%), 관련없는 반응 8개 (8.89\%), 형용사 전환 5개(5.68\%), 착어, 코딩불가 각 4 개(4.54\%), 신
조어 1개(1.11\%)로 나타났다. 즉, 동사 유형에 관계없이 실어증 환자 군이 보인 오류 반응 중 동사 유형 전환이 가장 많은 비율을 차지하 였다. 동사 유형별 오반응 유형의 빈도 및 비율에 대한 결과는 Table 3에 제시하였다.

\section{점화 동사 유형에 따른 정반응-주요 오반응 비율 교차분석}

실어증 집단에서의 정반응 및 오반응의 유형과 비율을 확인했 다. 그 결과, 가장 많은 비율을 차지하는 주요 오반응 유형은 동사 유형에 관계없이 동사 유형 전환으로 나타났다. 동사 유형별 정반 응 및 오반응 유형별 비율은 Figure 3에 제시하였다. 단, Figure 3에 서는 오반응 중 $10 \%$ 미만으로 출현한 유형은 제외한 후, 주요 오반 응 위주로 제시하였다.

Figure 3을 실펴보면, 동사 유형에 따라 정반응-주요 오반응 비율 의 차이가 나타남을 알 수 있다. 경동사에서는 동사 유형 전환이 정 반응보다 더 많은 비율을 차지하였고 중동사에서는 정반응이 동사 유형 전환보다 더 많은 비율을 차지하였다. 따라서 동사 유형에 따 른 정반응-주요 오반응 비율에 대한 차이가 통계적으로 유의한지

Table 3. Error type analyses in a verb priming task from people with aphasia

\begin{tabular}{lcc}
\hline Error type & Heavy verb priming & Light verb priming \\
\hline Verb type conversion (\%) & & 68 (77.27) \\
Another verb type production (\%) & $37(64.91)$ & Light to heavy conversion \\
Verb to adjective conversion (\%) & Heavy to light conversion & $5(5.68)$ \\
Etc (\%) & $3(5.26)$ & $4(4.54)$ \\
Paraphasia (\%) & & $4(4.54)$ \\
Unable to code (\%) & $0(0)$ & $1(1.11)$ \\
Neologism (\%) & $3(5.26)$ & $0(0)$ \\
Priming verb repetition (\%) & $1(1.75)$ & $8(8.89)$ \\
Irrelevant reaction (\%) & $3(5.26)$ & $90(100)$ \\
Total (\%) & $10(17.54)$ & $57(100)$ \\
\hline
\end{tabular}
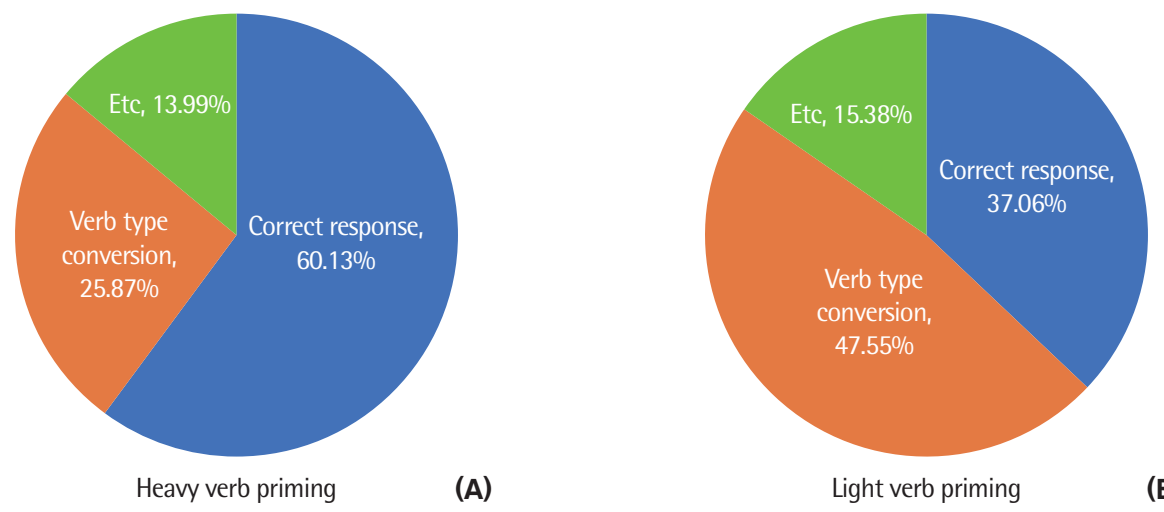

Figure 3. Proportion of error types for each verb type in people with aphasia. 
확인하기 위해 카이 제곱 검정을 실시하였다. 그 결과, 동사 유형에 따른 정반응-주요 오반응 비율에 대한 차이가 유의한 것으로 나타 났다 $\left(\chi^{2}=4.701, p<.05\right)$. 즉, 중동사에서는 정반응이 주요 오반응 에 유의하게 높은 비율을 차지하는 것에 비해 경동사에서는 주요 오반응 비율이 정반응에 비해 높은 것으로 확인되었다.

\section{논의 및 결론}

본 연구는 정상 성인과 실어증 환자를 대상으로 동사 유형(경동 사 및 중동사)에 따른 동사 점화 효과 및 오류 유형을 분석하여 집 단 간 차이를 알아보기 위해 실시하였다. 집단에 대한 주효과가 통 계적으로 유의하였다. 여러 선행연구와 같이(De Bleser \& Kauschke, 2003; Kim \& Thompson, 2000) 본 연구에서도 실어증 환자 집단에 서는 정상 집단에 비해 동사에서 어려움을 보였다. 동사는 문장의 구조나 시제에 따라 형태가 바뀌고(Lilla, 1990; Miller \& Fellbaun, 1991), 움직임을 나타내어 시각화하기 어려워(Berndt, Mitchum et al., 1997) 실어증 환자들이 어려워하는 것으로 보인다.

또한 동사 유형에 대한 주효과가 통계적으로 유의하였다. 이는 여러 선행연구에서 정상 성인 집단과 실어증 환자 집단에서 중동사 에 비해 경동사에서 어려움을 보인다는 결과와 의견이 일치한다 (Breedin, Saffran, \& Schwartz, 1998; Kim \& Thompson, 2004; Barde, Schwartz, \& Boronat, 2006). Kim과 Thompson (2004)은 정 상 집단, 실어증 집단, $\mathrm{PrAD}$ 집단에서 중동사와 경동사의 사용 양 상을 살펴보았다. 이 연구에 의하면 실어증 환자는 구문 손상으로 인해 문법가중치는 낮고 의미가중치가 높은 중동사를 더 빈번하게 사용하는 경향을 보이고, 치매 환자의 경우에는 의미 손상으로 인 하여 의미가중치가 낮으나 문법가중치가 높은 경동사의 산출률이 높다는 결론을 제시하였다. 한국어의 경우에는 경동사인 '하다'동 사는 서술명사와 결합하여 사용된다. 서술명사는 전통문법적으로 는 명사로 보아왔으나 일반명사에 비해 문장에서 논항을 부여하거 나 의미역을 결정하는 더욱 높은 문법적인 지식을 요구하는 명사이 며(Ahn \& Kang, 2000; Jung, 2016), 경동사가 갖지 않은 논항을 부 여하는 등 동사 기능을 하고 있다(Lee, 2004; Seo, 1975). 그러나 서 술명사 자체는 서술어의 역할을 할 수 없기에 경동사가 이에 결합 하여 서술어의 기능을 다할 수 있도록 한다. 그러나 교착어인 한국 어의 특징인 서술어의 활용은 경동사에서 일어난다. 한국어의 경 동사가 적절하게 사용되려면 이러한 서술명사의 적절한 이해와 산 출이 선행되어야 한다. 그러나 이러한 서술명사와 경동사의 결합체 는 중동사에 비해 복잡성을 띄고 있다고 볼 수 있다. 그 까닭은 중 동사는 그 자체에 의미적 지식과 문법적 지식이 포함되어 있으나,
경동사의 경우에는 서술명사에 의미적 지식과 문법적 지식이 포함 되어 있으며 이를 서술어의 형태로 적절하게 활용하기 위해 경동사 가 결합하여 사용된다. 따라서 실어증 환자들은 중동사보다 이러 한 서술명사와 경동사의 결합에서 어려움을 보여 경동사 점화 시 점화 동사 산출률이 낮았던 것으로 해석된다. 즉, 서술명사와 경동 사 결합의 복잡성이 정상 성인에 비해 실어증 환자에게서 더욱 어 려움으로 나타나는 것으로 해석할 수 있다.

반면 동사 유형에 따른 집단 간 상호작용 효과는 통계적으로 유 의하지 않았다. 동사 유형에 따른 상호작용이 유의하지 않은 이유 는 두 집단 모두 중동사에 비해 경동사에서 점화 동사 산출률이 감 소하였기 때문이다. 즉, 실어증 집단뿐만 아니라 정상 집단에서도 경동사 점화에서 점화 동사 산출률이 저하되었으며, 이로 인해 실 어증 환자 집단과 정상 집단 간의 차이에 유의한 영향을 미치지 않 는다는 것을 의미한다.

본 연구의 동사 점화 과제에서 실어증 환자가 보인 오류 반응을 분석한 결과, 가장 많은 비율을 차지한 주요 오반응 유형은 동사의 유형에 관계없이 동사 전환 오류로 나타났다. 또한, 동사 유형에 따 라 정반응-주요 오반응 비율의 차이를 살펴본 결과 경동사에서는 동사 유형 전환 오류가 정반응보다 더 많은 비율을 차지하였고 중 동사에서는 정반응이 동사 유형 전환 오류보다 비율이 높았다. 이 에 따라 차이 제곱 검정을 실시한 결과, 동사 유형에 따른 정반응주요 오반응 비율의 차이에서 통계적으로 유의한 차이가 나타났 다. 즉, 이러한 결과는 경동사에서는 점화 후에도 중동사로 전환하 는 오류 비율이 정반응에 비해 큰 것에 비해 중동사에서는 정반응 률이 여전히 오류에 비해 높은 비율을 보인 것으로 해석된다. 실어 증에서 이러한 현상이 나타난 이유는 경동사의 경우, '서술명사+경 동사'의 결합으로 중동사에 비해 명사 인출에 따른 처리부하가 추 가되어 실어증 환자가 동사 하나로만 이루어진 중동사에 비해 더 어려움을 보인 것에 기인한 것으로 보인다. 이러한 해석은 '서술명 사+경동사'의 결합이 서술명사의 명사적 특성과 용언적 특성에 서 술어의 역할을 위해 결합된 경동사의 용언적 특성이 추가됨에 따 라 더 어렵다는 선행연구와 일치하는 결과이다(Lee, 2009).

Kim과 Thompson (2004)의 지연-반복 과제를 사용한 연구에서 는 실어증 환자의 오류를 분석한 결과, 실어증 환자가 보이는 가장 높은 비율의 오반응은 문장에서 동사를 산출하지 못한 '동사 생략' 이었다. 이러한 반응은 정상 성인에게서 나타나지 않은 실어증 환자 의 특징적인 오류 반응이었다. 그러나 본 연구에서 실어증 환자의 오류 반응을 분석했을 때 동사 유형에 관계없이 동사 유형 전환이 가장 많은 비율을 보였다. 이는 한국어 환자들이 목표한 반응을 보 이지는 않았으나 산출한 문장 내에서 동사가 생략되지는 않았다고 
해석할 수 있다. 이러한 결과는 한국어권 실어증 환자들이 영어권 실어증 환자들에 비해 동사에서 보이는 손상이 경하다는 이전의 연구 결과와 맥락을 같이하고 있다(Sung, DeDe, \& Lee, 2016). 한 국어권 실어증 환자의 동사 산출 결함이 영어권 실어증 환자에 비 해 경미함에도 불구하고, 한국어 사용 실어증 환자의 경우 중동사 에 비해 경동사에서 더 큰 어려움을 보이는 것이 확인되었다. 이는 경동사에서 가중되어 있는 '서술명사+경동사'의 결합에서 인출의 어려움이 중동사 인출의 어려움에 비해 더 큰 것에 기인하는 것으 로 해석할수 있다.

본 연구의 대상자는 실어증 환자와 정상 성인이 각 13 명으로 제 한된 데이터로 인해 본 연구의 결과를 실어증 전체 집단과 정상 성 인 집단으로 일반화하는 것에 한계가 있다. 따라서 향후 실어증 환 자의 동사 손상에 대한 자세한 연구가 이루어지기 위해서는 연령과 학력 등이 다양한 충분한 대상자의 수를 확보할 필요가 있다. 또한 본 연구에서는 그림 자극을 제시하는 동사 점화 과제를 통해 산출 된 동사를 분석해보았다. 이는 제시된 그림 자극에 따라 산출할 수 있는 동사가 제한적일 수 있다. 따라서 후속 연구에서는 더욱 동사 산출에 제약을 주지 않는 그림 설명하기 과제나 인터뷰와 같은 다 양한 연구과제를 통해 환자의 수행 능력을 비교 및 분석한다면 실 제적인 실어증 환자의 언어 특성을 확인하고 실어증 환자의 평가 및 중재에 더욱 용이한 연구가 될 것이다.

본 연구는 동사의 하위 유형을 경동사와 중동사로 나누어 실어 증 환자군의 점화 효과 및 오류 반응을 분석해보았다. 본 연구의 결 과는 향후 동사에 관련된 실어증 환자의 중재 및 평가에 대한 기초 자료를 제공할 수 있으며 국내 연구에서 부족한 실어증 환자군의 동사 하위 유형에 따른 손상 정도를 확인해보았다는 점에서 의의 가 있다.

\section{REFERENCES}

Ahn, H. D., \& Kang, M. Y. (2000). A Study on the syntax structure of Korean between English. Gyeongjin Cultural History.

Barde, L. H., Schwartz, M. F., \& Boronat, C. B. (2006). Semantic weight and verb retrieval in aphasia. Brain and Language, 97(3), 266-278.

Berndt, R. S., Haendiges, A. N., Mitchum, C. C., \& Sandson, J. (1997). Verb retrieval in aphasia 2. Relationship to sentence processing. Brain and Language, 56(1), 107-137.

Berndt, R. S., Mitchum, C. C., Haendiges, A. N., \& Sandson, J. (1997). Verb retrieval in aphasia 1. Characterizing single word impairments. Brain and Language, 56(1), 68-106.
Breedin, S. D., \& Martin, R. C. (1996). Patterns of verb impairment in aphasia: an analysis of four cases. Cognitive Neuropsychology, 13(1), 51-91.

Breedin, S. D., Saffran, E. M., \& Schwartz, M. F. (1998). Semantic factors in verb retrieval: an effect of complexity. Brain and language, 63(1), 1-31.

Christensen, K. J., Multhaup, K. S., Nordstrom, S., \& Voss, K. (1991). A cognitive battery for dementia: development and measurement characteristics. Psychological Assessment: A Journal of Consulting and Clinical Psychology, 3(2), 168-174.

De Bleser, R., \& Kauschke, C. (2003). Acquisition and loss of nouns and verbs: parellel or divergent patterns? Journal of Neurolinguistics, 16(2-3), 213-229.

Diane, F. M. (2017). Effects of semantic weight on verb retrieval in individuals with aphasia: a different perspective. Journal of Communication Disorders, 69, 119-129.

Godefroy, O., Dubois, C., Debachy, B., Leclerc, M., \& Kreisler, A. (2002). Vascular aphasias: main characteristics of patients hospitalized in acute stroke units. Stroke, 33(3), 702-705.

Jung, D. S. (2016). Reviewing the discussion of the Korean light verb. Linguistics, 76, 87-116.

Kang, B. M., \& Kim, H. K. (2009). Frequency of using Korean. Seoul: Han'guk Munhwasa.

Kang, Y., Na, D. L., \& Hahn, S. (1997). A validity study on the Korean Mini Mental State Examination (K-MMSE) in dementia patients. Journal of the Korean Neurological Association, 15(2), 300-308.

Kang, Y., \& Na, D. L. (2003). Seoul neuropsychological screening battery. Seoul: Human Brain Research \& Consulting Co.

Kim, H., \& Na, D. L. (2012). Paradise.Korean Version of the Western Aphasia Battery Revised (PK-WAB-R). Seoul: Paradise Welfare Foundation.

Kim, M., \& Thompson, C. K. (2000). Patterns of comprehension and production of nouns and verbs in agrammatism: implications for lexical organization. Brain and Language, 74(1), 1-25.

Kim, M., \& Thompson, C. K. (2004). Verb deficits in Alzheimer's disease and agrammatism: implications for lexical organization. Brain and Language, 88(1), 1-20.

Kiss, K. (2000). Effect of verb complexity on agrammatic aphasics' sentence production. In R. Bastiaanse, \& Y. Grodzinsky (Eds.), Grammatical disorders in aphasia: a neurolinguistic perspective (pp.152-170). London: Whurr. Lilla, G. (1990). The structural sources of verb meanings. Language Acquisition. 1(1), 3-55.

Lee, B. K. (2009). Korean predicate noun grammar. Han'guk Munhwasa. 
Lee, J. T. (2004). The meaning structure of the upper level of the Korean light verb and the verb category. General Discussion on Humanities, 12, 5-14.

Miller, G. A., \& Fellbaum, C. (1991). Semantic networks of English. Cognition, 41(1-3), 197-229.

Ministry of Health and Welfare. (2009). 2009 sample hospital damage type and cause statistics survey. Sejong: Ministry of Health and Welfare.

Nam, G. S. (2001). Contemporary Korean syntax. Seoul: Taehaksa.

National Institute of Korean Language. (2010). Sejong literary language corpus. Seoul: Author.

Park, C. H. (2012). Statistical approach about ellipsis of Korean and English focused on ellipsis of subject and object. Journal of the Society of Korean Language and Literature, 66, 171-191.

Park, Y. B. (2014). Syntax and semantic analysis of functional verb '-Nada'. Proceedings of the Journal of the Korean Language Society, 151-161.

Sarah, D. B., Eleanor, M. S., \& Myrna, F. S. (1998). Semantic factors in verb retrieval: an effect of complexity. Brain and Language, 63(1), 1-31.

Seo, J. S. (1975). The function of the verb 'ha-'. Korean Language and Literature, 68, 262-265.
Seo, S. K. (1998). Word frequency in modern Korean language. Seoul: Language and Information Development Center, Yonsei University.

Sung, J. E., DeDe, G., \& Lee, S. E. (2016). Cross-linguistic differences in a picture-description task between Korean- and English-speaking individuals with aphasia. American Journal of Speech-Language Pathology, 25(4S), S813-822.

Sung, J. E., \& Kwak. E. J. (2012). Age-related verb naming abilities depending on the argument structures. Communications Sciences \& Disorders, 17(4), 550-564.

White-Devine, T., Grossman, M., Robinson, K. M., Onishi, K., \& Biassou, N. (1996). Verb confrontation naming and word-picture matching in Alzheimer's disease. Neuropsychology, 10(4), 495-503.

Yoon, J., \& Kim, Y. T. (2002). The category specificity in Korean Broca's aphasia patients: the impairment of verb comprehension. Korean Journal of Communication \& Disorders, 7(3), 39-54.

Zingeser, L. B., \& Berndt, R. S. (1990). Retrieval of nouns and verbs in agrammatism and anomia. Brain and Language, 39(1), 14-32. 
Appendix 1. 점화 문장 및 목표 문장 목록

\begin{tabular}{|c|c|c|}
\hline 점화 동사 유형 & 점화 문장 & 목표 문장 \\
\hline \multirow[t]{10}{*}{ 중동사 } & 남자가 사과를 깎다 & 남자가 생선을 자르다 / 손질하다 \\
\hline & 남자가 낙서를 지다 & 남자가 벌집을 없애다 / 제거하다 \\
\hline & 남자가 피리를 불다 & 남자가 피아노를 치다 / 연주하다 \\
\hline & 남자가 제비를 뽑다 & 남자가 옷을 고르다 / 선택하다 \\
\hline & 남자가 고기를 굽다 & 남자가 찌개를 끓이다 / 요리하다 \\
\hline & 남자가 책상을 닦다 & 남자가 바닥을 쓸다 / 청소하다 \\
\hline & 남자가 화단을 가꾸다 & 남자가 트리를 꾸미다 / 장식하다 \\
\hline & 남자가 블록을 쌓다 & 남자가 건물을 짓다 / 건설하다 \\
\hline & 남자가 화분을 들다 & 남자가 상자를 옮기다 / 운반하다 \\
\hline & 남자가 여자를 안다 & 남자가 친구를 달래다 / 위로하다 \\
\hline \multirow[t]{12}{*}{ 경동사 } & 남자가 노인을 부축하다 & 남자가 여자를 돌보다 / 간호하다 \\
\hline & 남자가 길을 안내하다 & 남자가 수학을 가르치다 / 설명하다 \\
\hline & 남자가 비행기를 조종하다 & 남자가 자동차를 몰다 / 운전하다 \\
\hline & 남자가 다리를 치료하다 & 남자가 기계를 고치다 / 수리하다 \\
\hline & 남자가 꽃을 구경하다 & 남자가 개미를 보다 / 관찰하다 \\
\hline & 남자가 도자기를 제작하다 & 남자가 티브이를 만들다 / 생산하다 \\
\hline & 남자가 점수를 기록하다 & 남자가 보고서를 쓰다 / 작성하다 \\
\hline & 남자가 무게를 비교하다 & 남자가 키를 재다 / 측정하다 \\
\hline & 남자가 일정을 변경하다 & 남자가 건전지를 바꾸다 / 교환하다 \\
\hline & 남자가 피자를 분배하다 & 남자가 책을 나누다 / 분류하다 \\
\hline & 남자가 돈을 저축하다 & 남자가 우표를 모으다 / 수집하다 \\
\hline & 남자가 작물을 경작하다 & 남자가 과일을 따다 / 수확하다 \\
\hline
\end{tabular}


Appendix 2. 오류 유형의 설명 및 예시

\begin{tabular}{ll}
\hline 오류 유형 & \multicolumn{1}{c}{$\begin{array}{c}\text { 설명 믹 예시 } \\
\text { 목표 } \rightarrow \text { 대상자 반응 }\end{array}$} \\
\hline $\begin{array}{c}\text { 타유형 서술어 전환 } \\
\text { 동사 유형 전환 }\end{array}$ & $\begin{array}{c}\text { 점화 동사와 다른 유형의 동사를 산출 } \\
\text { 예) 남자가 여자를 간호하다 } \rightarrow \text { 남자가 열을 재다 }\end{array}$ \\
형용사 전환 & 서술어로 형용사를 산출 \\
& 예) 남자가 블록을 쌓다 $\rightarrow$ 남자가 블록이 있다 \\
점화 동사 반복 & 점화 동사를 반복하여 산출함 \\
& 이와 같은 경우 그림과 불일치하거나 비문이 됨 \\
& 예) 남자가 국을 끓이다 $\rightarrow$ 남자가 국을 굽다 \\
착어 & 의미착어, 음소착어 \\
& 예) 남자가 우표를 수집하다 $\rightarrow$ 남자가 모집하다 \\
신조어 & 신조어 \\
& 예) 남자가 상자를 쌓다 $\rightarrow$ 남자가 모다 \\
코딩불가 & 반응없음, jargon \\
무관련 반응 & 제공된 자극과 관련없는 반응 \\
& 예) 남자가 피아노를 치다 $\rightarrow$ 남자가 말를 외우다 \\
\hline
\end{tabular}




\section{국문초록}

\section{실어증 환자의 점화 동사 유형에 따른 경동사 및 중동사 산출 능력 비교}

\section{김규연 · 성지은}

이화여자대학교 언어병리학과

배경 및 목적: 본 연구는 동사 점화 과제를 통해 실어증 환자와 정상 성인 간 동사 점화 효과를 확인해보고자 하였다. 방법: 좌반구 손 상에 기인한 실어증 환자 13 명과 나이, 교육년수, 성별을 일치시킨 정상 성인 13 명, 총 26 명이 실험에 참여하였다. 본 연구에서는 Kim과 Thompson (2004)의 연구에서 사용된 과제를 참고하여 동사 점화 과제를 제작하였다. 동사 점화 과제를 실시하여 각 집단별 점화 동사 산출률과 오류 유형을 분석하였다. 결과: 실어증 환자 집단이 정상 성인 집단에 비해 점화 동사 산출률이 유의하게 낮았다. 경동사가 중 동사에 비해 점화율이 유의하게 낮았다. 반면 그룹-동사 유형 간 상호작용은 유의하지 않았다. 실어증 환자의 오류 유형을 분석한 결과, 동사 유형에 관계없이 동사 유형 전환으로 나타났다. 경동사에서는 주요 오반응이 정반응에 비해 많은 비율을 보였으며 중동사에서는 정반응이 오반응에 비해 많은 비율이 나타났다. 논의 및 결론: 한국어 실어증 환자는 경동사가 중동사에 비해산출의 어려움을 보인다 는 것을 시사한다. 이는 정상 성인에게도 보이는 경향이며, 실어증 환자가 보이는 특성은 한국어의 정상적인 언어적 특성을 반영하고 있 다. 본 연구에서 경동사 산출의 어려움은 '서술명사+경동사'의 결합의 복잡성으로 설명할 수 있다. '서술명사+경동사'의 결합이 서술명 사의 명사적 특징과 용언적 특징에 경동사의 용언적 특성이 추가됨에 따라 중동사에 비해 상대적으로 어려움이 증가되었다. 이러한 복 잡성의 증가가 정상 성인에 비해 실어증 환자에게 더욱 영향을 미치는 것으로 해석할 수 있다.

핵심어: 실어증, 점화 효과, 경동사, 중동사, 동사 하위 유형

본 연구는 2019년도 대한민국 교육부와 한국연구 재단의 지원을 받아 수행된 연구임(No. NRF-2019R1A2C1089280).

\section{참고문헌}

강범모, 김흥규(2009). 한국어 사용 빈도. 한국문화사.

강연욱, 나덕렬, 한승혜(1997). 치매환자들을 대상으로 한 K-MMSE의 타당도연구 Journal of the Korean Neurological Association, 15(2), 300-308. 국립국어원(2010). 세종 현대문어 말뭉치. 서울: 국립국어원.

김향희, 나덕렬(2012). 파라다이스 · 한국판-웨스턴 실어증 검사(개정판). 서울: 파라다이스복지재단.

남기심(2001). (현대 국어) 통사론. 서울: 태학사.

박융배(2014). 기능동사 ‘나다'의 통사· 의미적 분석. 한국언어학회 학술대회지, 151-161.

박청희(2012). 한국어와 영어의 생략 현상에 대한 통계적 접근. 어문논집, 66, 171-191.

보건복지부(2009). 2009년 표본병원 손상유형 및 원인통계 조사. 세종: 보건복지부.

서상규(1998). 연세 말뭉치 1-9를 대상으로 한 현대한국어의 어휘빈도-빈도 7이상, 연세대학교 언어정보개발연구원 내부보고서. 서울: 연세대학교 언 어정보개발연구소.

서정수(1975). 동사'하-'의 기능. 국어국문학, 68, 262-265.

성지은, 곽은정(2012). 연령 및 동사 논항 구조에 따른 애니메이션을 활용한 동사 이름대기 과제 수행력 차이. Communications Sciences \& Disor-

ders, 17(4), 550-564.

안희돈, 강명윤(2000). 영어와 한국어의 통사구조 연구: 경동사, 동사구 이동, 부정문을 중심으로. 경진문화사.

윤정미, 김영태(2002). 브로카살어증 환자들의 동사이해결함의 범주특정적 특색. 언어청각장애연구, 7(3), 39-54.

이병규(2009). 한국어술어명사문 문법.서울: 한국문화사. 
이정택(2004). 동사 경동사(light verb)와 동사범주 상층부의 의미구조. 인문논총, 12, 5-14.

정대식(2016). 한국어 경동사 논의에 대한 검토. 언어학, 76, 87-116.

\section{ORCID}

김규연(제1저자, 대학원생 https://orcid.org/0000-0003-0837-9660); 성지은(교신저자, 교수 https://orcid.org/0000-0002-1734-0058) 